\title{
Assessment of the Content of Dietary Trans Fatty Acids and Biologically Active Substances in Cow's Milk and Curd
}

\author{
Silviya Ivanova*, Ljubomir Angelov \\ Email address: \\ sylvia_iv@abv.bg (S. Ivanova), luboangelov@abv.bg (L. Angelov) \\ ${ }^{*}$ Corresponding author
}

Department of Food Technology of Animal Origin, Institute of Cryobiology and Food Technology, Sofia, Bulgaria

\section{To cite this article:}

Silviya Ivanova, Ljubomir Angelov. Assessment of the Content of Dietary Trans Fatty Acids and Biologically Active Substances in Cow's Milk and Curd. Modern Chemistry. Vol. 5, No. 6, 2017, pp. 86-92. doi: 10.11648/j.mc.20170506.11

Received: September 26, 2017; Accepted: October 14, 2017; Published: November 8, 2017

\begin{abstract}
The present study aims to establish the content of natural trans fatty acids (TFA), biologically active and anticancerogenic components in cow's milk, obtained from the Bulgarian Rhodope Cattle breed and the curd produced by it during the lactation, and to evaluate the fatty acid composition of milk fat as a healthy source of human nutrition. The insurance of livestock with nutritional resource rich of linoleic and alpha linolenic acid on pasture grass rearing cows leads to an increase the quality in the fat fraction of milk in terms of biologically active fatty acids- omega-3, omega-6, CLA, trans and cis-fatty acids and decreases the amount of saturated fatty acids. The production of curd does not lead to substantial changes in the fatty acid composition resulting from well-conducted and respected technological processing. The assessment of the lipid preventive score, atherogenic and thrombogenic index in the milk and the curds produced by it give us an idea of the usefulness of the given product- high lipid preventive score and atherogenic index (over 1.0) and low cholesterolemic index (less than 1.0). The studied cow's milk are characterized by product as low content of trans fatty acids (from 0.11 to $0.21 \mathrm{~g} /$ $100 \mathrm{ml}$ product) and high amount of saturated fatty acids, the results obtained of curd are similarly- product with low content of trans fatty acids ( 0.34 to $1.09 \mathrm{~g} / 100 \mathrm{~g}$ product) and a high amount of saturated fatty acid content (from 12.63 to $19.96 \mathrm{~g} / 100 \mathrm{~g}$ product).
\end{abstract}

Keywords: Cow's Milk, Curd, Trans Fatty Acids, Indices

\section{Introduction}

Milk is the main raw material for the production of dairy products and its quality determines the quality of the subsequent technological products. The production of a highquality organic product depends on a number of factors such as breed, genetic heredity, nutritional technology, growing conditions, climatic conditions and etc. Markov [2] found that between milk yield and milk constituents there are too narrow and versatile phenotypic and genotypic interdependencies, and the differences between animals in terms of milk fat are to a much greater extent due to hereditary differences than in terms of milk yield, the inheritance ratio being relatively high. The composition of feed, diet and season, influence the milk yield and chemical composition of milk [3]. The nutritional behavior of purebreed animals and crosses shows rhythm and increased intensity despite some differences. The ethological features of the calves - the nutritional, the motor, the general activity have an important selection meaning when assembling herds. The indices of nutritional and motor activity are related to the age and physiological condition of the animals. Peacefulness along with the same manifestation of reflections in the case of intake of fodder, are signs that are enshrined in future generations $[4,5]$.

Curd is a milk product obtained by coagulation of proteins in milk, whey from cheese or yellow cheese or buttermilk and, depending on the raw material, is divided into milky, whey and humbly. According to the method of production, curd is rennet acid, lactic acid and rennet, with no lactic acid fermentation. The milk fat content of milk determines curd as whole fat $(20 \%$ fat $)$, semi-skim fat ( $10 \%$ fat) and skim fat. It is obtained from cow's milk, buttermilk or a mixture of them. Curd is a high protein product - skim fat - 19-20\%, semiskimmed and whole fat - about 14-15\% (12). By content and 
digestibility of amino acids, curd is one of the most complete dairy products. Of particular value are the sulfur-containing amino acids (methionine, cystine and cysteine) and choline. The prophylactic role and dietary importance of curd is determined primarily by the completeness of its amino acid composition. Whey curd, which contains only lacto albumins and lacto globulins, has high absorption and highlights protective and healing properties in liver, cardiovascular, kidney, gastrointestinal and other diseases. Milk and curd are one of the most valuable products in prophylactic nutrition (in hazardous conditions) and in rational nutrition, especially for adolescents and people of mental work.

Acharya and Katwal [6], in the production of fresh Paneer cheese using different types of acids and at different concentrations, found that the use of $1 \%$ citric acid and $2 \%$ lactic acid for the optimal production of thermally coagulated cheese, as the higher concentrations of the total solid decrease inversely to the concentration of the introduced acid.

Prandini et al., [1], found that in the organic production of milk and dairy products the values of conjugated linoleic acid (CLA), vaccenic acid (TVA) and linolenic acid (LNA) compared to conventional samples were higher and the technological processing did not have a significant impact on their concentration. Changes in the content of CLAs and biologically active components in milk are determined by the diet of ruminants based on fresh or dried feed, a high concentration of CLA precursor fatty acids, which can improve the yield of fatty acids with beneficial effects on health.

Diets rich in saturated fatty acids such as lauric (C12: 0), myristic (C14: 0), palmitic (C16: 0) and stearic acid (C18: 0) are strongly associated with an increased risk of atherosclerosis, obesity and coronary heart disease (9). According to the indices proposed by Ulbricht and Southgate (1991), lauric (C12: 0), myristic (C14: 0) and palmitic acid (C16: 0) have an atherogenic character, but a myristic (C14: $0)$ palmitic (C16: 0) and stearic acid (C18: 0) as thrombogenic character, whereas omega-3, omega- 6 and monounsaturated fatty acids have antiatherogenic and antithrombogenic character. The thrombogenic and atherogenic index, as indicators, should not exceed 1.00 while the cholesterol index is above 1.00 [8]. Souza, et al., [7] found in cow's milk an atherogenic index- 4.10 and a thrombogenic index- 5.17. The daily intake of trans fatty acids should not exceed $0.5 \%$ of the energy intake. According to EU Regulation No 1924/2006 of the European Parliament and of the Council on 20 December 2006, the content of saturated fatty acids and trans fatty acids in solid products does not exceed $1.5 \mathrm{~g} / 100 \mathrm{~g}$ or $0.75 \mathrm{~g} / 100 \mathrm{ml}$ liquid, and in both cases the content of saturated fatty acids and trans fatty acids does not exceed $10 \%$ of the daily energy intake and these foods are referred to as low content of saturated fatty acids foods. The claim that a food does not contain SFA may only be indicated if the SFA and TFA content does not exceed $0.1 \mathrm{~g} / 100 \mathrm{~g}$ product or $0.1 \mathrm{~g} / 100 \mathrm{ml}$ liquid [Regulation (EC) No 1924 / 2006(10)].

The present study aims to establish the content of natural trans fatty acids (TFA), biologically active and anticancerogenic components in cow's milk obtained from the Bulgarian Rhodope Cattle breed and the curd produced by it during the lactation, and to evaluate the fatty acid composition of milk fat as a healthy source of human nutrition.

\section{Material and Methods}

\subsection{Analysis Material}

The studies were carried out in the villages of Tarin and Smolyan (Middle Rhodopes) on the feed source of ruminants under natural pasture grass conditions (May-July) and in indoor condition with the following diet: lucerne hay, pellet sugar beet and concentrated fodder (May-July). Three herds were used, two of which were free pasture grass rearing and one of indoor rearing, from which individual and bulk tank milk samples were taken to assess the composition of milk and the production of curd.

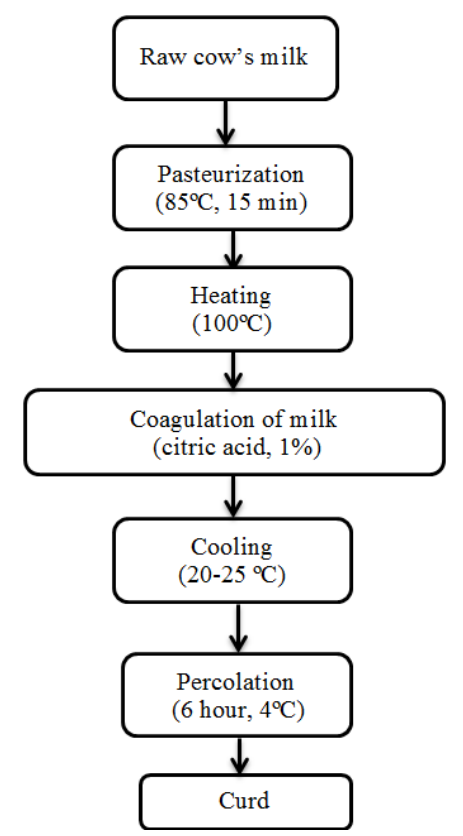

Figure 1. Process scheme of curd production.

\subsection{Analysis Method}

1. Humidity - BSS 1109: 1989, ISO 9622.

2. Total Solids- BSS 1109: 1989, ISO 9622.

3. Protein- ISO 9622, BSS EN ISO 8968-1: 2002.

4. Fat - BSS EN ISO 1211: 2002, ISO 9622.

5. Ash content - BSS 6154: 1974

6. Extraction of total lipids is performed by the method of Bligh \& Dyer (feed) and Roese \& Gottlieb (milk and dairy products). Fatty acid methyl esters (FAME) were analyzed using a Shimadzu-2010 gas chromatograph (Kyoto, Japan).

\subsection{Qualitative Assessment}

The qualitative assessment of the fat fraction comprises the following parameters: lipid preventive score (LPS), atherogenic (AI) and thrombogenic (TI) index [11], the ratio between hyperand hypocholesterolemic $(\mathrm{h} / \mathrm{H})$ fatty acids, trans fatty acids and 
the amount of saturated fatty acids (SFA) (10).

LPS $=$ FAT $+2 x$ SFA- MUFA- 0,5 PUFA

$\mathrm{AI}=12: 0+4 \times 14: 0+16: 0 /[\Sigma \mathrm{MUFAs}+\mathrm{PUFA}$ n6+PUFA n3] $\mathrm{TI}=(14: 0+16: 0+18: 0) /[0.5 \times \Sigma \mathrm{MUFAs}+0.5 \times \mathrm{PUFA}$ n6+3 $\times$ PUFA n-3+PUFA n3/ PUFA n6]

$\mathrm{h} / \mathrm{H}=(\mathrm{C} 18: 1 \mathrm{n}-9+\mathrm{C} 18: 1 \mathrm{n}-7+\mathrm{C} 18: 2 \mathrm{n}-6+\mathrm{C} 18: 3 \mathrm{n}-3+\mathrm{C} 18: 3 \mathrm{n}-$ $6+\mathrm{C} 20: 3 n-6+C 20: 4 n-6+C 20: 5 n-3+C 22: 4 n-6+C 22: 5 n-$

$3+\mathrm{C} 22: 6 \mathrm{n}-3) /(\mathrm{C} 14: 0+\mathrm{C} 16: 0)$

\section{Results and Discussion}

The fatty acids profile of pasture grass used to feed the animals in free pasture rearing as vegetation progresses and the major groups of fatty acids undergo substantial changes. Saturated fatty acids decrease from 30.70 to $18.51 \mathrm{~g} / 100 \mathrm{~g}$ of fat (1.65 times), monounsaturated fatty acids (MUFA) decrease 2.3 times, while polyunsaturated fatty acids (PUFA) increase by 0.73 times. The reason a decrease in the content of saturated fatty acids is a decrease the amount of lauric acid (C12: 0), myristic (C14: 0), palmitic (C16: 0) and stearic (C18: 0), and monounsaturated fatty acids are the isomers of oleic acid. Of particular interest represent is the dynamical changes in the linoleic $(\mathrm{C} 18: 2$ cis 9,12) and $\alpha$-linolenic acid, which are a substrate for CLA synthesis (anticancerogenic activity) in the rumen of ruminants. The concentration of C18: 2 increases from 11.87 to $19.18 \mathrm{~g} / 100 \mathrm{~g}$ fat on the MayJuly period, and in alpha-linolenic acid from 42.78 to 56.47 $\mathrm{g} / 100 \mathrm{~g}$ of fat.

When using of feed in the indoor cow's rearing is established a decrease in saturated fatty acids from 23.96 to $21.44 \mathrm{~g} / 100 \mathrm{~g}$ fat, an increase in monounsaturated fatty acids from 18.10 to $20.69 \mathrm{~g} / 100 \mathrm{~g}$ fat and preservation of the content in polyunsaturated fatty acids 57.66 and $57.77 \mathrm{~g} / 100 \mathrm{~g}$ fat. The change in monounsaturated fatty acids is due to an increase in C18: 1cis9 content from 16.31 to $18.97 \mathrm{~g} / 100 \mathrm{~g}$ fat. The concentration of linoleic acid increases from 42.17 to $47.65 \mathrm{~g} / 100 \mathrm{~g}$ fat and in alpha- linolenic acid it decreases from 15.30 to $10.01 \mathrm{~g} / 100 \mathrm{~g}$ fat (Table 1 ).
Table 1. Fatty acid composition of the nutritional resours used to feed on the animals $(\mathrm{g} / 100 \mathrm{~g}$ fat $)$.

\begin{tabular}{lllll}
\hline \multirow{2}{*}{ FA } & \multicolumn{2}{l}{ Pasture grass } & Fodder \\
\cline { 2 - 5 } & May & July & May & July \\
\hline SFA & 30,70 & 18,51 & 23,96 & 21,44 \\
MUFA & 12,50 & 5,40 & 18,10 & 20,69 \\
PUFA & 55,34 & 75,77 & 57,66 & 57,77 \\
TFA & 2,37 & 0,38 & 0,69 & 0,75 \\
CFA & 7,51 & 3,21 & 16,38 & 19,05 \\
$\Sigma \mathrm{n}-3$ & 42,86 & 56,57 & 15,37 & 10,01 \\
$\Sigma \mathrm{n}-6$ & 12,69 & 19,19 & 42,30 & 47,78 \\
$\Sigma \mathrm{n}-6 / \Sigma \mathrm{n}-3$ & 0,35 & 0,35 & 2,75 & 4,77 \\
BFA & 0,24 & 0,13 & 0,09 & 0,06 \\
\hline
\end{tabular}

The total fats in the studied cow's milk ranged from 3.24 to $5.10 \%$ in first pasture area, while in the other they remained relatively stable from 6.06 to $6.08 \%$ with a decrease in the middle of the period, while in the indoor rearing decrease on June to $4.49 \%$. The protein content is relatively constant, with higher concentrations being obtained in the second group of pasture grass. There are no changes in lactose as a result of different diet regimens. The total solids are higher in the second grazing group and in the indoor rearing group. No valid differences in the physicochemical parameters of milk in pasture and indoor rearing cows were found (Table 2).

In the lactation period were determined a decrease in the amount of somatic cells, bacteria and coliforms as a result of pasture grass rearing. In the studies performed on the microbiological parameters of the milk, a reliable change in the number of somatic cells in the first and second group of grazing ( $* * * \mathrm{P}<0,001)$ and in the pasture grass on the first group relative to the indoor group (** $\mathrm{P}<0.01)$, while in the lactation, they credibly decreased in the first group of pasture rearing May / July and June / July $(* * \mathrm{P}<0.01)$ respectively, and in the second group of grazing on May / June with * $\mathrm{P}<$ 0.05. The obtained results of somatic cell count and individual bacteria cells during the lactation in an improvement in the microbiological picture of milk and compliance with hygiene standards.

Table 2. Physicochemical composition of cows' milk obtained from pasture grass and indoor rearing.

\begin{tabular}{|c|c|c|c|c|c|c|c|}
\hline \multirow{2}{*}{ Indicator } & & \multicolumn{2}{|l|}{ May } & \multicolumn{2}{|l|}{ June } & \multicolumn{2}{|l|}{ July } \\
\hline & & $\mathbf{X}$ & SD & $\mathbf{X}$ & SD & $\mathbf{X}$ & SD \\
\hline \multirow{3}{*}{ Fat, $\%$} & $\mathrm{P} 1$ & 3,24 & 1,45 & 4,26 & 0,67 & 5,10 & 1,07 \\
\hline & $\mathrm{P} 2$ & 6,06 & 0,01 & 5,40 & 0,68 & 6,08 & 1,09 \\
\hline & I & 5,02 & 0,55 & 4,49 & 0,45 & 5,02 & 0,35 \\
\hline \multirow{3}{*}{ Protein, $\%$} & $\mathrm{P} 1$ & 3,48 & 0,42 & 3,45 & 0,23 & 3,22 & 0,24 \\
\hline & $\mathrm{P} 2$ & 4,39 & 0,31 & 4,18 & 0,25 & 4,22 & 0,09 \\
\hline & I & 3,33 & 0,03 & 3,35 & 0,20 & 3,25 & 0,15 \\
\hline \multirow{3}{*}{ Lactose, $\%$} & $\mathrm{P} 1$ & 4,47 & 0,18 & 4,48 & 0,19 & 4,32 & 0,31 \\
\hline & $\mathrm{P} 2$ & 4,53 & 0,26 & 4,44 & 0,10 & 4,24 & 0,20 \\
\hline & I & 4,48 & 0,02 & 4,57 & 0,18 & 4,45 & 0,28 \\
\hline \multirow{3}{*}{ Total solids, $\%$} & $\mathrm{P} 1$ & 12,16 & 1,92 & 12,95 & 0,65 & 13,39 & 1,41 \\
\hline & $\mathrm{P} 2$ & 15,96 & 0,49 & 14,78 & 1,02 & 14,96 & 1,34 \\
\hline & I & 13,81 & 0,50 & 13,16 & 0,49 & 13,47 & 0,42 \\
\hline \multirow{3}{*}{ Solids non fat, $\%$} & $\mathrm{P} 1$ & 8,91 & 0,51 & 4,71 & 5,93 & 8,31 & 0,52 \\
\hline & $\mathrm{P} 2$ & 8,77 & 0,05 & 6,32 & 1,83 & 9,26 & 0,28 \\
\hline & I & 9,87 & 0,50 & 8,69 & 0,65 & 8,47 & 0,92 \\
\hline \multirow{3}{*}{ Freezing point, $\%$} & $\mathrm{P} 1$ & 0,53 & 0,01 & 0,53 & 0,01 & 0,53 & 0,01 \\
\hline & $\mathrm{P} 2$ & 0,54 & 0,02 & 0,53 & 0,01 & 0,52 & 0,00 \\
\hline & I & 0,52 & 0,00 & 0,53 & 0,01 & 0,53 & 0,01 \\
\hline
\end{tabular}




\begin{tabular}{|c|c|c|c|c|c|c|c|}
\hline \multirow{2}{*}{ Indicator } & & \multicolumn{2}{|l|}{ May } & \multicolumn{2}{|l|}{ June } & \multicolumn{2}{|l|}{ July } \\
\hline & & $\mathbf{X}$ & SD & $\mathbf{X}$ & SD & $\mathbf{X}$ & SD \\
\hline \multirow{3}{*}{ Somatic cell, cell/ml } & $\mathrm{P} 1$ & $\begin{array}{l}1126,86 \\
b^{* *}, c^{* *}, d^{* * *}\end{array}$ & 1067,03 & 927,50 & 1010,63 & 534,17 & 476,01 \\
\hline & $\mathrm{P} 2$ & $342,33 \mathrm{a}^{*}$ & 454,50 & 111,33 & 49,66 & 244,33 & 251,50 \\
\hline & I & 298,00 & 33,94 & 460,00 & 50,96 & 510,00 & 25,46 \\
\hline \multirow{3}{*}{$\mathrm{IBC}$, cell $/ \mathrm{ml}$} & $\mathrm{P} 1$ & 6985710,00 & 18083,88 & 632600,00 & 252062,10 & 634833,33 & 349439,79 \\
\hline & $\mathrm{P} 2$ & 4768000,00 & 3552,17 & 5713500,00 & 7476240,00 & 915333,33 & 201777,93 \\
\hline & I & 1011000,00 & 97,58 & 1254000,00 & 273540,00 & 243000,00 & 16894,14 \\
\hline
\end{tabular}

$* * * \mathrm{P}<0,001, * * \mathrm{P}<0,01,{ }^{*} \mathrm{P}<0,05 ; \mathrm{a}-$ May/June, b- May/July, c- June/July, d- P1/P2, e-P1/I.

IBC- Individual Bacteria Cells, X- Average, SD- Standard deviation.

The fatty acid composition of cow's milk fat is presented in Table 3. Saturated fatty acids increase from 64.67 to 66.06 $\mathrm{g} / 100 \mathrm{~g}$ fat in the first region and from 71.14 to $75.55 \mathrm{~g} / 100 \mathrm{~g}$ fat in the second, while in the case of indoor rearing they decrease from 66,96 to $63,39 \mathrm{~g} / 100 \mathrm{~g}$ fat. Monounsaturated fatty acids (MUFA) in the rearing of livestock grow from 28.29 to $30.89 \mathrm{~g} / 100 \mathrm{~g}$ fat, while in grazing they vary and in the middle of the period they decrease and finally increase again. Polyunsaturated fatty acids were the lowest in the three groups on July, respectively $3.88,2.59,2.93 \mathrm{~g} / 100 \mathrm{~g}$ fat. The trans fatty acids in the analyses milk decreased during the lactation in pasture grass rearing, while the indoor were varied very narrow limits and increased at the end of the period under consideration (from 3.89 to $4.20 \mathrm{~g} / 100 \mathrm{~g}$ fat). The cis isomers were found to decrease from 21.18 to $16.80 \mathrm{~g} / 100 \mathrm{~g}$ fat in the second group of pasture rearing. The CLA content of the analyses milk samples shows that depending on the nutritional value, the amount is different. In natural food sources, CLA levels are reduced as follows: from 1.13 to $0.63 \mathrm{~g} / 100 \mathrm{~g}$ fat and from 0.52 to $0.36 \mathrm{~g} / 100 \mathrm{~g}$ fat, while in the indoor rearing are fluctuates from 0,74 to $0.84 \mathrm{~g} / 100 \mathrm{~g}$ fat. Omega-3 fatty acids are higher in milk obtained from free pasture grass from 0.72 to $0.69 \mathrm{~g} / 100 \mathrm{~g}$ fat. Similar results are found for omega- 6 fatty acids -2.35 to $2.61 \mathrm{~g} / 100 \mathrm{~g}$ fat in pasture grass feed and from 2.49 to $2.18 \mathrm{~g} / 100 \mathrm{~g}$ fat in indoor rearing.

Table 3. Fatty acid composition obtained from pasture grass and indoor rearing ( $\mathrm{g} / \mathrm{l} 00 \mathrm{~g}$ fat).

\begin{tabular}{|c|c|c|c|c|c|c|}
\hline \multirow{3}{*}{ FA } & \multicolumn{6}{|l|}{ May } \\
\hline & \multicolumn{2}{|l|}{ P1 } & \multicolumn{2}{|l|}{$\mathbf{P 2}$} & \multicolumn{2}{|l|}{ I } \\
\hline & $\mathbf{X}$ & SD & $\mathbf{X}$ & SD & $\mathbf{X}$ & SD \\
\hline SFA & 64,67 & 4,51 & 71,14 & 8,99 & 66,96 & 2,94 \\
\hline MUFA & $29,70 \mathrm{~d}^{*}, \mathrm{e}^{*}$ & 4,33 & 24,87 & 9,74 & 28,29 & 1,50 \\
\hline PUFA & $4,13 \mathrm{e}^{* * *}$ & 0,68 & 2,91 & 0,86 & 3,76 & 0,49 \\
\hline TFA & $6,33 \mathrm{~d}^{*}$ & 4,53 & 2,59 & 1,34 & 3,82 & 1,53 \\
\hline CFA & $21,87 \mathrm{e}^{*}, \mathrm{~d}^{*}$ & 3,48 & 21,18 & 8,74 & 23,47 & 0,16 \\
\hline$\Sigma \mathrm{n}-3$ & 0,72 & 0,13 & 0,61 & 0,04 & 0,67 & 0,11 \\
\hline$\sum n-6$ & $2,35 \mathrm{e}^{*}$ & 0,23 & 1,86 & 0,89 & 2,49 & 0,02 \\
\hline$\sum n-6 / \sum n-3$ & 3,35 & 0,55 & 3,12 & 1,67 & 3,80 & 0,62 \\
\hline CLA 9c,11t & 1,13 & 0,61 & 0,52 & 0,05 & 0,74 & 0,35 \\
\hline
\end{tabular}

\begin{tabular}{|c|c|c|c|c|c|c|c|c|c|c|c|c|}
\hline \multirow{3}{*}{ FA } & \multicolumn{6}{|l|}{ June } & \multicolumn{6}{|l|}{ July } \\
\hline & \multicolumn{2}{|l|}{ P1 } & \multicolumn{2}{|l|}{$\mathbf{P 2}$} & \multicolumn{2}{|l|}{ I } & \multicolumn{2}{|l|}{ P1 } & \multicolumn{2}{|l|}{ P2 } & \multicolumn{2}{|l|}{ I } \\
\hline & $\mathbf{X}$ & SD & $\mathbf{X}$ & SD & $\mathbf{X}$ & SD & $\mathbf{X}$ & SD & $\mathbf{X}$ & SD & $\mathbf{X}$ & SD \\
\hline SFA & 63,40 & 6,99 & 76,52 & 3,35 & 66,86 & 3,62 & 66,06 & 3,34 & 75,55 & 6,24 & 63,39 & 3,62 \\
\hline MUFA & 26,52 & 1,33 & 19,37 & 2,10 & 29,09 & 2,65 & 30,01 & 3,78 & 20,47 & 5,94 & 30,89 & 2,65 \\
\hline PUFA & 4,28 & 0,26 & 2,64 & 0,18 & 4,07 & 0,57 & 3,88 & 0,59 & 2,59 & 1,25 & 2,93 & 0,57 \\
\hline TFA & 3,51 & 0,79 & 2,01 & 0,33 & 3,86 & 1,07 & 2,62 & 1,10 & 1,82 & 0,92 & 4,20 & 1,07 \\
\hline$\Sigma$ CLA & 0,82 & 0,35 & 0,52 & 0,25 & 0,80 & 0,15 & 0,74 & 0,40 & 0,48 & 0,43 & 1,10 & 0,15 \\
\hline$\Sigma \mathrm{n}-3$ & 0,87 & 0,06 & 0,62 & 0,06 & 0,57 & 0,22 & 0,69 & 0,16 & 0,50 & 0,44 & 0,79 & 0,22 \\
\hline$\Sigma \mathrm{n}-6$ & 2,72 & 0,15 & 1,61 & 0,33 & 2,98 & 0,23 & 2,61 & 0,39 & 1,75 & 0,44 & 2,18 & 0,23 \\
\hline$\sum n-6 / \sum n-3$ & 3,15 & 0,20 & 2,64 & 0,72 & 5,21 & 0,06 & 3,91 & 0,78 & 3,52 & 1,01 & 2,76 & 0,06 \\
\hline CLA 9c, 11t & 0,78 & 0,36 & 0,50 & 0,26 & 0,75 & 0,48 & 0,63 & 0,35 & 0,36 & 0,41 & 0,84 & 0,48 \\
\hline
\end{tabular}

*** $\mathrm{P}<0,001,{ }^{*} \mathrm{P}<0,01,{ }^{*} \mathrm{P}<0,05$; a- May/June, b- May/July, c- June/July, d- P1/P2, e-P1/I.

$\mathrm{X}$ - Average, SD- Standard deviation.

The lipid prevantive score (LPS), atherogenic (AI) and thrombogenic (TI) index varied in the studied cow's milk, with the highest value being reported in the three groups on July, respectively, 9.93, 13.82 and 9.76 for LPS, and the lowest for the atherogenic and thrombogenic index on May. The trans fatty acid content ranged from 0.11 to 0.21 for individual groups of milk during the lactation period (Table 4). 
Table 4. Quality characteristics of fat fraction in milk, obtained from pasture grass and indoor rearing cow's (g/100g product).

\begin{tabular}{|c|c|c|c|c|c|c|}
\hline \multirow{3}{*}{$\begin{array}{l}\text { FA } \\
\text { Index }\end{array}$} & \multicolumn{6}{|l|}{ May } \\
\hline & \multicolumn{2}{|l|}{ P1 } & \multicolumn{2}{|l|}{ P2 } & \multicolumn{2}{|l|}{$\mathbf{I}$} \\
\hline & $\mathbf{X}$ & SD & $\mathbf{X}$ & SD & $\mathbf{X}$ & SD \\
\hline LPS & $6,84 \mathrm{~d}^{* *}, \mathrm{e}^{* * *}$ & 3,95 & 13,09 & 1,74 & 8,76 & 2,66 \\
\hline AI & $1,88 \mathrm{~d}^{* *}, \mathrm{e}^{* *}$ & 0,28 & 3,23 & 2,04 & 2,29 & 0,18 \\
\hline TI & $2,05 \mathrm{e}^{* *}, \mathrm{~d}^{* *}$ & 0,37 & 3,27 & 1,55 & 2,43 & 0,17 \\
\hline $\mathrm{h} / \mathrm{H}$ & $0,69 \mathrm{e}^{* *}, \mathrm{~d}^{*}$ & 0,09 & 0,58 & 0,38 & 0,62 & 0,02 \\
\hline TFA & 0,20 & 0,11 & 0,16 & 0,08 & 0,17 & 0,09 \\
\hline SFA+TFA & $2,44 \mathrm{e}^{* *}, \mathrm{~d} * * *$ & 1,33 & 4,47 & 0,47 & 3,05 & 0,92 \\
\hline
\end{tabular}

\begin{tabular}{|c|c|c|c|c|c|c|c|c|c|c|c|c|}
\hline \multirow{3}{*}{$\begin{array}{l}\text { FA } \\
\text { Index }\end{array}$} & \multicolumn{6}{|l|}{ June } & \multicolumn{6}{|c|}{ uly } \\
\hline & \multicolumn{2}{|l|}{ P1 } & \multicolumn{2}{|l|}{ P2 } & \multicolumn{2}{|l|}{$\mathbf{I}$} & \multicolumn{2}{|l|}{ P1 } & \multicolumn{2}{|l|}{ P2 } & \multicolumn{2}{|l|}{ I } \\
\hline & $\mathbf{X}$ & SD & $\mathbf{X}$ & SD & $\mathbf{X}$ & SD & $\mathbf{X}$ & SD & $\mathbf{X}$ & SD & $\mathbf{X}$ & SD \\
\hline LPS & 9,04 & 1,23 & 12,51 & 1,33 & 9,10 & 1,95 & 9,93 & 2,99 & 13,82 & 1,60 & 9,76 & 2,48 \\
\hline AI & 2,30 & 0,07 & 4,18 & 0,51 & 2,08 & 0,45 & 1,96 & 0,34 & 4,10 & 1,50 & 2,07 & 0,61 \\
\hline TI & 2,27 & 0,31 & 3,96 & 0,32 & 2,18 & 0,25 & 2,22 & 0,22 & 4,03 & 1,28 & 2,24 & 0,25 \\
\hline $\mathrm{h} / \mathrm{H}$ & 0,65 & 0,04 & 0,34 & 0,04 & 0,73 & 0,13 & 0,75 & 0,15 & 0,38 & 0,14 & 0,64 & 0,03 \\
\hline TFA & 0,16 & 0,02 & 0,11 & 0,03 & 0,17 & 0,05 & 0,13 & 0,07 & 0,12 & 0,08 & 0,21 & 0,02 \\
\hline $\mathrm{SFA}+\mathrm{TFA}$ & 3,03 & 0,30 & 4,23 & 0,45 & 3,18 & 1,76 & 3,41 & 1,06 & 4,67 & 0,56 & 3,40 & 0,78 \\
\hline
\end{tabular}

***P $<0,001,{ }^{* *} \mathrm{P}<0,01,{ }^{*} \mathrm{P}<0,05$; a- May/June, b- May/July, c- June/July, d- P1/P2, e-P1/I, f- P2/I, X- Average, SD- Standard deviation.

The fatty acid composition of the milk fat in produced curd is shown in Table 5. Saturated fatty acids in the first series decrease by $1 \%$ compared to the starting milk and range from 63.90 to $65.95 \mathrm{~g} / 100 \mathrm{~g}$ of fat, whereas in the curd made from milk of second region of pasture grass rearing increase from 79.15 on May and kept on July $74.92 \mathrm{~g} / 100 \mathrm{~g}$ fat, while in the milk from indoor rearing decrease by $6 \%$ on May and $0.2 \%$ on July, which was caused by the processing technology. Monounsaturated (MUFA) and polyunsaturated fatty acids in the technology process respectively increase from 1 to $5 \%$ and decrease to $1 \%$ relative to the starting material and keep the amount during the lactation period. The trans fatty acids in the studied curds are relatively stable and there are slight variations between the obtained curds and the starting milk, which is between 0.5 and $1 \%$. Similar results are received for cis isomers. The content of CLA, omega- 3 and omega- 6 fatty acids in the analyzed curd largely retains its concentration of starting milk indicating that the curd production does not cause any significant change in CLA, omega-3 or omega-6 fatty acids content after the process of pasteurization.

Table 5. Fatty acid composition of curd obtained from milk of pasture grass and indoor rearing cow's ( $\mathrm{g} / 100 \mathrm{~g}$ fat).

\begin{tabular}{|c|c|c|c|c|c|c|}
\hline \multirow{3}{*}{ FA } & \multicolumn{6}{|l|}{ May } \\
\hline & \multicolumn{2}{|l|}{ P1 } & \multicolumn{2}{|l|}{$\mathbf{P 2}$} & \multicolumn{2}{|l|}{ I } \\
\hline & $\mathbf{X}$ & SD & $\mathbf{X}$ & SD & $\mathbf{X}$ & SD \\
\hline SFA & 63,90 & 4,51 & 79,15 & 8,99 & 60,57 & 11,34 \\
\hline MUFA & 30,08 & 4,33 & 16,56 & 9,74 & 27,39 & 0,13 \\
\hline PUFA & 4,13 & 0,68 & 2,51 & 0,86 & 3,07 & 0,55 \\
\hline TFA & 6,06 & 4,53 & 1,47 & 1,34 & 2,84 & 0,25 \\
\hline CFA & 22,88 & 3,48 & 14,23 & 8,74 & 21,10 & 3,24 \\
\hline$\sum n-3$ & 0,71 & 0,13 & 0,58 & 0,04 & 0,45 & 0,12 \\
\hline$\sum n-6$ & 2,40 & 0,23 & 1,69 & 0,89 & 2,91 & 0,46 \\
\hline$\sum n-6 / \sum n-3$ & 3,36 & 0,55 & 2,90 & 1,67 & 6,82 & 2,79 \\
\hline CLA 9c, 11t & 1,12 & 0,61 & 0,36 & 0,05 & 0,51 & 0,04 \\
\hline
\end{tabular}

\begin{tabular}{|c|c|c|c|c|c|c|c|c|c|c|c|c|}
\hline \multirow{3}{*}{ FA } & \multicolumn{6}{|l|}{ June } & \multicolumn{6}{|l|}{ July } \\
\hline & \multicolumn{2}{|l|}{ P1 } & \multicolumn{2}{|l|}{ P2 } & \multicolumn{2}{|l|}{ I } & \multicolumn{2}{|l|}{ P1 } & \multicolumn{2}{|l|}{$\mathbf{P 2}$} & \multicolumn{2}{|l|}{ I } \\
\hline & $\mathbf{X}$ & SD & $\mathbf{X}$ & SD & $\mathbf{X}$ & SD & $\mathbf{X}$ & SD & $\mathbf{X}$ & SD & $\mathbf{X}$ & SD \\
\hline SFA & 68,52 & 6,99 & 73,30 & 3,35 & 65,69 & 3,62 & 65,95 & 0,31 & 74,92 & 6,24 & 63,19 & 3,62 \\
\hline MUFA & 25,75 & 1,33 & 20,24 & 2,10 & 29,88 & 2,65 & 30,28 & 0,23 & 22,18 & 5,94 & 34,51 & 2,65 \\
\hline PUFA & 4,16 & 0,26 & 2,73 & 0,18 & 4,06 & 0,57 & 4,23 & 0,00 & 2,93 & 1,25 & 3,61 & 0,57 \\
\hline TFA & 3,66 & 0,79 & 2,09 & 0,33 & 4,19 & 1,07 & 3,04 & 0,17 & 1,88 & 0,92 & 3,69 & 1,07 \\
\hline CFA & 20,97 & 1,04 & 17,17 & 1,69 & 24,84 & 1,66 & 25,04 & 0,04 & 17,52 & 4,16 & 28,67 & 1,66 \\
\hline$\Sigma$ CLA & 0,89 & 0,35 & 0,57 & 0,25 & 0,81 & 0,15 & 0,86 & 0,00 & 0,57 & 0,43 & 0,93 & 0,15 \\
\hline$\Sigma \mathrm{n}-3$ & 0,79 & 0,06 & 0,65 & 0,06 & 0,58 & 0,22 & 0,95 & 0,00 & 0,67 & 0,44 & 0,49 & 0,22 \\
\hline$\Sigma \mathrm{n}-6$ & 2,61 & 0,15 & 1,63 & 0,33 & 3,07 & 0,23 & 0,77 & 0,02 & 1,81 & 0,44 & 2,42 & 0,23 \\
\hline$\sum n-6 / \sum n-3$ & 3,30 & 0,20 & 2,51 & 0,72 & 5,32 & 0,06 & 3,58 & 0,13 & 2,70 & 1,01 & 4,92 & 0,06 \\
\hline CLA 9c,11t & 0,87 & 0,36 & 0,54 & 0,26 & 0,76 & 0,48 & 0,83 & 0,00 & 0,53 & 0,41 & 0,88 & 0,48 \\
\hline
\end{tabular}

$\mathrm{X}$ - Average, SD- Standard deviation. 
The lipid preventive score in the investigated curds ranged from 42.69 to 60.29 , the atherogenic index was higher at the beginning of the analyzed period and in one group reached to 5.02 and the thrombogenic to 4.35 . The analyses curds are characterized as a food product with a low content of trans fatty acid from 0.42 to $1.09 \mathrm{~g} / 100 \mathrm{~g}$ product and a high content of saturated fatty acid from 12.63 to $19.96 \mathrm{~g} / 100 \mathrm{~g}$ product (Table 6).

Table 6. Qualitative characteristics of curd obtained from milk of pasture grass and indoor rearing cow's ( $\mathrm{g} / 100 \mathrm{~g}$ of product).

\begin{tabular}{lllllll}
\hline \multirow{2}{*}{ FA } & \multicolumn{2}{l}{ May } & & & & I \\
\cline { 2 - 6 } & P1 & SD & P2 & SD & X & SD \\
\cline { 2 - 6 } & X & 1,86 & 58,31 & 2,65 & 44,97 & 2,99 \\
LPS & 44,91 & 0,13 & 5,02 & 0,35 & 2,14 & 0,14 \\
AI & 2,10 & 0,18 & 4,35 & 0,26 & 2,02 & 0,18 \\
TI & 2,21 & 0,16 & 0,32 & 0,01 & 0,64 & 0,21 \\
h/H & 0,66 & 0,01 & 0,34 & 0,02 & 0,69 & 0,08 \\
TFA & 1,09 & 1,04 & 18,76 & 1,32 & 15,12 & 1,09 \\
SFA+TFA & 12,63 & & & & \\
\hline
\end{tabular}

\begin{tabular}{|c|c|c|c|c|c|c|c|c|c|c|c|c|}
\hline \multirow{3}{*}{ FA } & \multicolumn{6}{|l|}{ June } & \multicolumn{6}{|l|}{ July } \\
\hline & \multicolumn{2}{|l|}{ P1 } & \multicolumn{2}{|l|}{ P2 } & \multicolumn{2}{|l|}{ I } & \multicolumn{2}{|l|}{ P1 } & \multicolumn{2}{|l|}{ P2 } & \multicolumn{2}{|l|}{ I } \\
\hline & $\mathbf{X}$ & SD & $\mathbf{X}$ & SD & $\mathbf{X}$ & SD & $\mathbf{X}$ & SD & $\mathbf{X}$ & SD & $\mathbf{X}$ & SD \\
\hline LPS & 57,82 & 1,79 & 60,29 & 3,12 & 46,57 & 2,78 & 51,08 & 2,69 & 42,69 & 1,94 & 47,05 & 1,65 \\
\hline $\mathrm{AI}$ & 2,60 & 0,18 & 4,07 & 0,27 & 2,01 & 0,13 & 3,44 & 0,37 & 1,96 & 0,16 & 1,94 & 0,29 \\
\hline TI & 2,57 & 0,24 & 3,93 & 0,37 & 2,10 & 0,16 & 3,44 & 0,24 & 2,22 & 0,17 & 2,21 & 0,14 \\
\hline $\mathrm{h} / \mathrm{H}$ & 0,59 & 0,01 & 0,36 & 0,02 & 0,74 & 0,02 & 0,39 & 0,02 & 0,74 & 0,09 & 0,74 & 0,07 \\
\hline TFA & 1,01 & 0,15 & 0,53 & 0,13 & 0,98 & 0,02 & 0,42 & 0,01 & 0,65 & 0,04 & 0,75 & 0,09 \\
\hline SFA+TFA & 19,96 & 1,27 & 19,09 & 1,08 & 16,32 & 1,04 & 17,34 & 1,01 & 14,76 & 1,18 & 16,29 & 1,39 \\
\hline
\end{tabular}

$\mathrm{X}$ - Average, SD- Standard deviation.

\section{Conclusion}

Ensuring animal with nutritional resource rich in linoleic and alpha linolenic acid in pastute grass rearing cows leads to an increase the quality of fat fraction in milk on terms of biologically active fatty acids - omega-3, omega-6, CLA, trans and cis-fatty acids and reduces the amount of saturated fatty acids. The production of curd does not lead to substantial changes in the fatty acid composition resulting from well-conducted and respected technological processing. The assessment of the lipid preventive scores, atherogenic and thrombogenic index in the milk and the curds produced by it give us an idea of the usefulness of the given product- high lipid preventive score and atherogenic index (over 1.0) and low cholesterolemic index (less than 1.0). The analyzed cow's milk is characterized as a product with low content of trans fatty (from 0.11 to $0.21 \mathrm{~g} / 100 \mathrm{~g}$ product) and a high content of saturated fatty acids, similarly results are obtained for the curd- product with low content of trans fatty low-content product ( 0.34 to 1.09 $\mathrm{g} / 100 \mathrm{~g}$ product) and high content of saturated fatty acid (from 12.63 to $19.96 \mathrm{~g} / 100 \mathrm{~g}$ product).

\section{References}

[1] A. Prandini, S. Sigolo and G. Piva, Conjugated linoleic acid (CLA) and fatty acid composition of milk, curd and Grana Padano cheese in conventional and organic farming systems, Journal of Dairy Research, vol. 76, no. 3, pp. 278-282, 2009. doi: $10.1017 / \mathrm{S} 0022029909004099$.
[2] N. Markov, Influence of para-typical factors over milk production of bulgarian black-and-white cows in pleven region, Journal of Mountain Agriculture on the Balkans, vol. 16, no. 5, pp. 1079-1094, 2013a.

[3] N. Markov, Biological effectiveness of milk productivness of bulgarian black-white cattle in pleven region, Journal of Mountain Agriculture on the Balkans, vol. 16, no. 6, pp. 1450$1458,2013 b$.

[4] N. Markov, Behavioral reactions of female calves of bulgarian white and black cattle and of its' crossbreeds with hereford breed, Journal of Mountain Agriculture on the Balkans, vol. 16, no. 5, pp. 1108-1122, 2013c.

[5] N. Markov, and M. Markova, Features in the implementation of the productive potential of calves salerskata breeds and their crosses with bulgarian black-mot ley livestock, Journal of Mountain Agriculture on the Balkans, vol. 16, no. 6, pp. 1459-1458, 2013

[6] P. P. Acharya and B. K. Katwal, Effect of Coagulants on Paneer Quality Prepared from Market Milk, Nepal Journal of Science and Technology, vol. 4, pp. 1-4, 2002.

[7] C. F. Souza, A. C. R. de Aguiar, and D. P. D. Lanna, Physicochemical composition and fatty acid profile of milk from $\mathrm{F} 1$ Holstein $\mathrm{x}$ Zebu cows fed with increasing concentrations of urea, Ciências Agrárias, Londrina, vol. 36, no. 6, pp. 4435-4446, 2015. DOI: 10.5433/16790359.2015v36n6Supl2p4435 .

[8] A. Ivanova, and L. Hadzhinikolova, Evaluation of nutritional quality of common carp (Cyprinus carpio L.) lipids through fatty acid ratios and lipid indice, Bulg. J. Agric. Sci., Supplement 1, No. 21, pp. 180-185, 2015. 
[9] R. Pilarczyk, J. Wójcik, P. Sablik, and P. Czerniak, Fatty acid profile and health lipid indices in the raw milk of Simmental and Holstein-Friesian cows from an organic farm, South African Journal of Animal Science, vol. 45, no. 1, pp. 30-38, 2015.

[10] Regulation (EC) No 1924/2006 of the European Parliament and of the Council, 20 December 2006: "On nutrition and health claims made on foods". Trans fatty acids and insulin resistance. Atherosclerosis Suppl., vol. 7, pp. 37-39, 2006.
[11] T. L. Ulbricht, and D. A. Southgate, Coronary heart disease: Seven dietary factors, Lancet, vol. 338, no. 8773, pp. 985-992, 1991.

[12] T. Dimitrov, G. Mihailova, T. Iliev, and N. Naidenova. Milk and Dairy products with methods of investigation, Stara Zagora, 2008, 206 (Bg). 